\title{
Interpreting chemistry and technology of lime binders and implementing it in the conservation field Interpretação da química e da tecnologia de ligantes à base de cal e sua implementação no campo da conservação
}

\author{
Georgia Zacharopoulou \\ Civil \& Structural Engineer, M.A., PhD \\ Ephorate of Modern Monuments of Central Macedonia, Greek Ministry of Culture \\ Mouson 89, 54634 Thessaloniki, Greece \\ Tel. \& fax: 00302310215680 \\ E-mail: gzachar.heritage@gmail.com
}

\begin{abstract}
The objective of the paper is the compilation, review and dissemination of updated scientific knowledge on lime theory and technology in the field of heritage conservation. The strong evidence of the last decade's research on the positive effect of the - not demonstrable by a chemical equation - 'key' missing link of the maturation process is highlighted. It is demonstrated that the exceptional performance characteristics of durable lime based mortars predominately rely on the capacity for rapid, efficient and extensive carbonation of the air-hardening phase of limes, in particular when matured (nanoparticle wet slaked) lime putties are used; and on the chemical and mechanical stability of the strength components (principally CSHs) of the hydraulic phase of limes, which is higher in their more crystalline forms of historical lime-pozzolan mixtures than in their amorphous forms of modern cements. Hence, physicochemical adhesion and cohesion bonds both at the lime matrix and at the binder/aggregate interfaces are ensured imparting minimization of cracks and durability to lime based mortars and historic masonries. The comprehensive documentation of the former leads to optimal materials and procedures to preserve our cultural heritage.
\end{abstract}

\section{Keywords}

Maturation; Lime putty; Lime mortar; Strength components; Structural stability.

\section{Resumo}

O objectivo do presente artigo é a compilação, revisão e disseminação do actual conhecimento científico sobre teoria e tecnologia da cal no campo da conservação do património. Com base na investigação da última década, são destacados os fortes indícios do efeito positivo - não demonstrável por equação química - do elo perdido 'chave', o processo de maturação. É demonstrado que as excepcionais características de desempenho das argamassas à base de cal mais duráveis dependem predominantemente das suas capacidades para uma rápida, eficiente e extensa carbonatação da fase de presa aérea da cal, em particular quando é usada cal em pasta com maior tempo de maturação (extinção húmida ao nível das nanopartículas); e da estabilidade química e mecânica dos componentes de resistência (principalmente silicatos de cálcio hidratados (CSHs)) da fase hidráulica da cal, que é mais elevada nas formas mais cristalinas das misturas históricas de cal e pozolana do que nas formas amorfas dos cimentos modernos. Deste modo são asseguradas as ligações fisico-químicas por adesão e por coesão, quer na matriz de cal, quer nas interfaces ligante/agregado, conferindo minimização de fissuras e durabilidade a argamassas à base de cal e alvenarias históricas. Uma abrangente documentação destes processos permitirá a obtenção de materiais e procedimentos progressivamente mais adequados à preservação do nosso património cultural.

Palavras-chave

Maturação; Cal em pasta; Argamassa de cal; Componentes de resistência; Estabilidade estrutural. 


\author{
Abbreviations of cement chemistry \\ Silica/SiO $2 / \mathrm{S}$ \\ Alumina/ $\mathrm{Al}_{2} \mathrm{O}_{3} / \mathrm{A}$ \\ Di-calcium silicate $/ 2 \mathrm{CaO} \cdot \mathrm{SiO}_{2} / \mathrm{C}_{2} \mathrm{~S}$ \\ Tri-calcium silicate $/ 3 \mathrm{CaO} \cdot \mathrm{SiO}_{2} / \mathrm{C}_{3} \mathrm{~S}$ \\ Tri-calcium aluminate $/ 3 \mathrm{CaO} \cdot \mathrm{Al}_{2} \mathrm{O}_{3} / \mathrm{C}_{3} \mathrm{~A}$ \\ Calcium silicate hydrate/ $\mathrm{CaO} \cdot \mathrm{SiO}_{2} \cdot \mathrm{nH}_{2} \mathrm{O} / \mathrm{CSH}$ \\ Calcium aluminate hydrate/ $\mathrm{CaO} \cdot \mathrm{Al}_{2} \mathrm{O}_{3} \cdot \mathrm{nH}_{2} \mathrm{O} / \mathrm{CAH}$
}

\section{Introduction}

Lime has indisputably been documented as the diachronic building binder [1-14]. Knowledge on building limes and lime based mortars evolved gradually over many centuries. The process of development was mostly experienced empirically and was incorporated in representative texts before [15-18], during [19-22] or after the development of hydraulic binders [23-34].

It is assumed that the meticulous study of these papers could provide supportive information on traditional raw materials, productive processes, selection criteria, recipes and working techniques and would contribute positively to the success of current conservation practices. However, information derived from the past literature presents implications arising either from the incomplete descriptions of old mortar mixtures and application techniques or from misleading instructions (apparently because early practitioners were not aware of the significance of a certain ingredient or technique in the performance of a mortar) or even from the more or less intuitive desire to preserve the secrets of their workmanship $[35,36]$. Similarly, the unravelling of the history of lime through countless laboratory analysis of the surviving lime based mortars is very complicated [37], since all the applied techniques present some inherent inadequacies and limitations [38]. Detailed information, specifically on the methodologies used for mortar characterisation, can be found in published reviews [35-36, 39-42]. While acknowledging the value of both documentary [15-34] and analytical investigations into the question of the lime manufacture and performance, certain complications, though, have been multi-underlined [43-45].

It is imperative, thus, that building limes' processes understanding $[10,46]$ is regularly reviewed, revaluated and disseminated in current conservation practice, in a simplified as possible a way. In this frame, the present paper focuses on the effect of the lime binders' performance characteristics, since there is a general consensus on the influence of crucial parameters, such as the aggregate selection, their gradation, the binder/aggregate (B/A) and the water/binder $(w / b)$ ratios.

\section{Chemistry and technology of building limes processes}

\section{Raw materials}

Limestones (natural, plentiful, renewable local resources) can be classified into various groups; the updated classification of Table 1 both satisfies the conservation requirements and corresponds to European standard EN 459 'Building lime' by correlating the main types of limestones, which have been historically used for the production of building limes, with the chemical and mechanical characteristics of the produced quicklimes and hydrated limes [46-48].

\section{Calcination}

The maximum dissociation temperature of $\mathrm{CaCO}_{3}$ $\left(898^{\circ} \mathrm{C}\right)$ stated by Johnston (1910) and Mitchell (1923), and of $\mathrm{MgCO}_{3}\left(725^{\circ} \mathrm{C}\right)$ concluded by Linzell (1926) are still generally accepted [34, p.160]. Depending on the characteristics of the original limestones and on kiln type, key calcination factors - such as maximum temperature, rate of heating and retention time of calcination - present a certain degree of flexibility and only through experimentation can be optimized in order to produce highly reactive quicklimes [34, 49]. It is empirically and scientifically proved that the best, most reactive quicklimes are formed at mild production conditions approved historically by wood firing [49, p.43], i.e. if lime is softly burnt at low temperatures $\left(900-1000^{\circ} \mathrm{C}\right)[49$, p. $122 ; 50$, p.205; 51] giving special attention to slow preheating rates [49, p.122; 52].

Table 2 demonstrates the chemical reactions during the calcination of pure and high calcium limestones (case A: 1), and of magnesian (dolomitic) limestones (case $\mathrm{B}: 1$ ) that produce $\mathrm{CaO}$ (or $\mathrm{CaO} \cdot \mathrm{MgO}$ ) after the 
Table $1 \quad$ Classification of limestones and relevant types of building limes.

\begin{tabular}{|c|c|c|c|c|c|}
\hline \multicolumn{2}{|c|}{ RAW MATERIAL } & \multirow{2}{*}{$\begin{array}{c}\text { Chemical } \\
\text { Characteristics }\end{array}$} & \multirow{2}{*}{$\begin{array}{c}\text { QUICKLIME } \\
\text { Calcium } \\
\text { quicklime }\end{array}$} & \multirow{2}{*}{$\begin{array}{c}\begin{array}{c}\text { Mechanical } \\
\text { Characteristics } \\
\text { (historic mortars) }\end{array} \\
\begin{array}{c}\text { fat lime hydrate } \\
\text { (content } \mathrm{MgO}<5 \% \text { ) }\end{array}\end{array}$} & \multirow{2}{*}{$\begin{array}{c}\text { Current classification } \\
\text { according to EN } \\
\text { 459:2001 [47] rev. } 2010 \\
\text { air-hardening calcium } \\
\text { type CL90 } \\
\text { in the forms of putty/dry }\end{array}$} \\
\hline $\begin{array}{c}\text { PURE } \\
\text { LIMESTONES }\end{array}$ & $\begin{array}{l}\text { pure calcium } \\
\text { limestones }\end{array}$ & & & & \\
\hline \multirow{2}{*}{$\begin{array}{l}\text { EN459 } \\
\text { classification of } \\
\text { air-hardening } \\
\text { building limes } \\
\text { according to their } \\
\mathrm{CaO}+\mathrm{MgO} \\
\text { content }\end{array}$} & $\begin{array}{l}\text { high calcium } \\
\text { limestones }\end{array}$ & $\begin{array}{c}\text { content } \\
>94 \% \mathrm{CaCO}_{3} \text { and } \\
2-5 \% \mathrm{MgCO}_{3}\end{array}$ & $\begin{array}{l}\text { (very reactive if } \\
\text { produced under } \\
\text { mild conditions) }\end{array}$ & $\begin{array}{c}f^{1}=0.3-0.7 \mathrm{~N} / \mathrm{mm}^{2} \\
(B / A: 1 / 3,28 \mathrm{~d})\end{array}$ & $\begin{array}{l}\text { air-hardening calcium } \\
\text { types CL80, CL70 } \\
\text { in the forms of putty/dry }\end{array}$ \\
\hline & $\begin{array}{l}\text { magnesian/ } \\
\text { dolomitic } \\
\text { limestones }\end{array}$ & $\begin{array}{c}\text { content } \\
>54 \% \mathrm{CaCO}_{3} \text { and } \\
5-35 \% \mathrm{MgCO}_{3} / \\
35-46 \% \mathrm{MgCO}_{3}{ }^{2}\end{array}$ & $\begin{array}{l}\text { magnesian/ } \\
\text { dolomitic } \\
\text { quicklime }\end{array}$ & 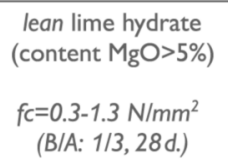 & $\begin{array}{l}\text { air-hardening dolomitic } \\
\text { types DL90, DL85, DL80 } \\
\text { in the forms of putty/dry }\end{array}$ \\
\hline \multirow{5}{*}{$\begin{array}{l}\text { LIMESTONES } \\
\text { WITH } \\
\text { IMPURITIES } \\
\text { EN459 } \\
\text { classification of } \\
\text { hydraulic building } \\
\text { limes according } \\
\text { to } 28 \text { days } \\
\text { compressive } \\
\text { strength (fc) }\end{array}$} & \multirow{5}{*}{$\begin{array}{l}\text { high calcium } \\
\text { limestones } \\
\text { or } \\
\text { magnesian/ } \\
\text { dolomitic } \\
\text { limestones } \\
\text { with } \\
\text { aluminosilicate } \\
\text { impurities }\end{array}$} & $\begin{array}{l}\text { content } \\
5-12 \% \text { active } \\
\text { aluminosilicate } \\
\text { impurities }\end{array}$ & 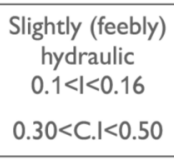 & $\begin{array}{l}\text { hardening time } \\
15-20 \text { days } \\
f_{c}=0.7-2.0 \mathrm{~N} / \mathrm{mm}^{2} \\
\text { (B/A: } 1 / 3,28 \mathrm{~d} \text {.) }\end{array}$ & $\begin{array}{c}\text { natural hydraulic type } \\
\text { NHL2, } 2-7 \mathrm{~N} / \mathrm{mm}^{2} \\
\text { in dry form }\end{array}$ \\
\hline & & $\begin{array}{l}\text { content } \\
12-18 \% \text { active } \\
\text { aluminosilicate } \\
\text { impurities }\end{array}$ & $\begin{array}{c}\text { moderately } \\
\text { hydraulic } \\
0.16<1<0.31 \\
0.50<\text { C. } 1<0.70\end{array}$ & $\begin{array}{l}\text { hardening time } \\
5-15 \text { days } \\
\text { fc=2.0-5.0 N/mm }{ }^{2} \\
\text { (B/A: } 1 / 3,28 \mathrm{~d} \text { ) }\end{array}$ & $\begin{array}{l}\text { natural hydraulic types } \\
\text { with no additives } \\
\text { NHL3.5, 3.5-10 N/mm } \\
\text { NHL5, } 5-15 \mathrm{~N} / \mathrm{mm}^{2} \\
\text { only in dry form }\end{array}$ \\
\hline & & $\begin{array}{c}\text { content } \\
18-25 \% \text { active } \\
\text { aluminosilicate }\end{array}$ & $\begin{array}{l}\text { eminently } \\
\text { hydraulic } \\
0.42<1<0.50\end{array}$ & $\begin{array}{l}\text { hardening time } \\
\sigma \varepsilon 1-4 \text { days }\end{array}$ & $\begin{array}{c}\text { modern natural hydraulic } \\
\text { types } \\
\text { with additives (hydraulic } \\
\text { and/or pozzolanic) } \\
\text { (compulsory declaration of } \\
\text { contents) } \\
\text { NHL-Z2, NHL-Z3.5, } \\
\text { NHL-Z5 } \\
\text { (currently under revision as } \\
\text { FL-formulated limes) }\end{array}$ \\
\hline & & $\begin{array}{l}\text { aluminosilicate } \\
\text { impurities }\end{array}$ & $0.70<C .1<1.10$ & $\begin{array}{l}f c=5-10 \mathrm{~N} / \mathrm{mm}^{2} \\
(B / A: 1 / 3,28 \mathrm{~d} .)\end{array}$ & $\begin{array}{c}\text { or } \\
\text { artificial hydraulic } \\
\text { HL2, HL3.5, HL5 } \\
\text { with additives } \\
\text { (not compulsory declaration } \\
\text { of contents) }\end{array}$ \\
\hline & & & & & $\begin{array}{l}\text { or furthermore } \\
\text { types of cements } \\
\text { only in dry form }\end{array}$ \\
\hline
\end{tabular}

'According to EN 459-1: 2001 'Building lime', $f c=$ mean values of the 28day compressive strength in $\mathrm{N} / \mathrm{mm}^{2}$, for binder/aggregate ratio (B/A):(1/3).

${ }^{2}$ Classification according to ANSI/ASTM C51-71:1976. The higher percentage of $\mathrm{MgCO}_{3}\left(35,46 \% \mathrm{MgCO}_{3}\right)$ states that the raw material is not suitable for lime production, except for special purposes.

${ }^{3}$ L.J. Vicat was the first who classified the limestones with impurities based on their active silicates and aluminates content; Hydraulic Index, $\mathrm{I}=\left[\% \mathrm{SiO}_{3}+\% \mathrm{Al}_{2} \mathrm{O}_{3}+\left(\% \mathrm{Fe}_{2} \mathrm{O}_{3}\right)\right] /[\% \mathrm{CaO}+\% \mathrm{MgO}]$. He also proposed simple methods of testing their hydraulicity and recommended the correct use of each type [20]. In 1920's, a modified but more accurate classification of hydraulic lime types was developed by inserting suitable gravitation coefficients for each component $[20,24,28,33]-$ the Cementation Index, C.I. $=\left[(2.8) \times \% \mathrm{SiO}_{3}+(1.1) \times \% \mathrm{Al}_{2} \mathrm{O}_{3}+(0.7) \times \% \mathrm{Fe}_{2} \mathrm{O}_{3}\right] /[\% \mathrm{CaO}+(1.4) \times \% \mathrm{MgO}][29,33]$. Natural cements have $1.1<C . I<1.7$, hardening time $15 \mathrm{~min}, 2 \mathrm{~h}$ and compressive strength $\mathrm{fc}>10 \mathrm{~N} / \mathrm{mm}^{2}$ (for $B / A: 1 / 3,28 \mathrm{~d}$.). The above indexes incorrectly suggest that the oxides are all active, for this reason more accurate calculations of C.I. are currently proposed. The new EN 459-1: 2001 'Building lime' adopts the classification according to 28days compressive strength, e.g. for NHL 2, NHL 3.5, NHL 5 (fc): 2,7, 3.5, 10 and 5, 15 N/mm² respectively [46, p. 7] and according to their $\mathrm{CaO}+\mathrm{MgO}$ content for the air-hardening types. 
decomposition of the carbonates i.e. air-hardening quicklimes (CL - calcium or DL - dolomitic types).

The calcination of limestones with impurities (natural or artificially introduced, case D: 1) produces hydraulic binders with varying degrees of reactivity (Table 1: slightly, moderately or eminently hydraulic) related to the amount of silica and alumina included in the original impure limestone (NHL types) or added (HL types) [47]. During the burning process an amount of lime reacts with the silica and the alumina and anhydrous calcium silicates and aluminates are formed (mineral hydraulic phases). NHL types of limes do not contain any other additives, while NHL-Z - currently under revision as FL-formulated lime - and $\mathrm{HL}$ types may include further hydraulic and/or pozzolanic material (Table 1) [47, 48].

The reactive phases of hydraulic limes and early portland cements - where maximum temperature was kept below $1250{ }^{\circ} \mathrm{C}$ and thus clinker by sintering could not be produced - were principally unbound $\mathrm{CaO}$ (air-hardening phase) and silicates and aluminates (hydraulic phase). It is argued [34,53-56] that the hydraulic properties of hydraulic limes can be mostly attributed to the di-calcium silicate (belite $\mathrm{C}_{2} \mathrm{~S}$ ) and in some degree to the tri-calcium aluminate $\left(\mathrm{C}_{3} \mathrm{~A}\right)$.

In comparison, the predominant reactive component of modern cements (case $\mathrm{E}: 1$ ) is the tri-calcium silicate (alite $\mathrm{C}_{3} \mathrm{~S}$ ), which is responsible for their more rapid hardening and higher ultimate strengths.

\section{Hydration}

The term hydration is a chemical term which, in the current context, generally expresses the chemical reaction with water of both the air-hardening and the potential hydraulic phases of a binder. For limes with hydraulic components, the second phase of this reaction is directly connected to the strength development process.

The term slaking (wet or dry) is a technological term that describes the process (by hand or mechanical means) of hydration of both the air-hardening and hydraulic limes with no connection to the strength development mechanism. It mainly matches to wet slaking process of air-hardening limes. Historically, natural and artificial hydraulic limes are mainly produced with reduction to powder by dry slaking - aiming to hydrate only their unbound phases $(\mathrm{CaO}$ or $\mathrm{CaO} \cdot \mathrm{MgO})$ - with or without grinding [47; 49, p.22]. Cements, apparently, cannot be slaked and they are available in the market after grinding.

The hydration of pure quicklimes that produce (by wet or dry slaking) air hardening hydrated limes is demonstrated in Table 2 . In case A: 2.1, high calcium quicklime, which is very reactive (if evenly burnt at low temperature, as previously analyzed), reacts violently with water to form calcium hydroxide $\mathrm{Ca}(\mathrm{OH})_{2}$.

In case B: 2.1 , dolomitic quicklimes slake very slowly and they can fully hydrate only under pressure (sub case (a), where $\mathrm{MgO}$ is often hard burned) or the component of magnesium oxide may not slake at all (sub case (b), where $\mathrm{MgO}$ is almost dead burned) [49, p.122]. A probable late slaking of the $\mathrm{MgO}$, however, may develop detrimental expansion and loss of bond in mortars [34, 50].

The hydration of natural or artificial hydraulic quicklimes that produce (by dry slaking process) hydraulic hydrated limes occurs more slowly and less vigorously. The hydration of their two different phases (air-hardening and hydraulic) does not occur simultaneously; firstly, during the dry slaking, only the $\mathrm{CaO}$ (or $\mathrm{CaO} \cdot \mathrm{MgO}$ ) slakes/hydrates (case D: 2.1), while during the second step, the aluminosilicates (the hydraulic phases) react with water, and hydrated calcium silicates and aluminates $(\mathrm{CSH} \& \mathrm{CAH})$ are produced (and also an amount of portlandite $\mathrm{Ca}(\mathrm{OH})_{2}$ as a soluble by-product of the hydration process), through a complicated chemical mechanism (case D: 2.2) similar to the hardening of portland cement (case E: 2.2) [34, 37, 54-56].

In-between, case C (Table 2) describes a major technological achievement, where traditional local pozzolans (natural or artificial sources of amorphous silica and alumina) are simply added to air-hardening local limes (together with aggregates, water or admixtures) to manufacture the first type of hydraulic mortar in human history at room temperature.

It is well-known that wet slaking favours the colloidal rather than the crystallised character of the produced hydrated limes by altering their particle size distribution [37, 49, 56-59]. The implication of such a difference (colloidal versus crystallised) is related to the irreplaceable properties of the wet slaked limes such as plasticity, workability, high water retentiveness, high sand carrying capacity and high reactivity $[34,56]$. Despite the guidance of old texts and centuries of experience, in current 


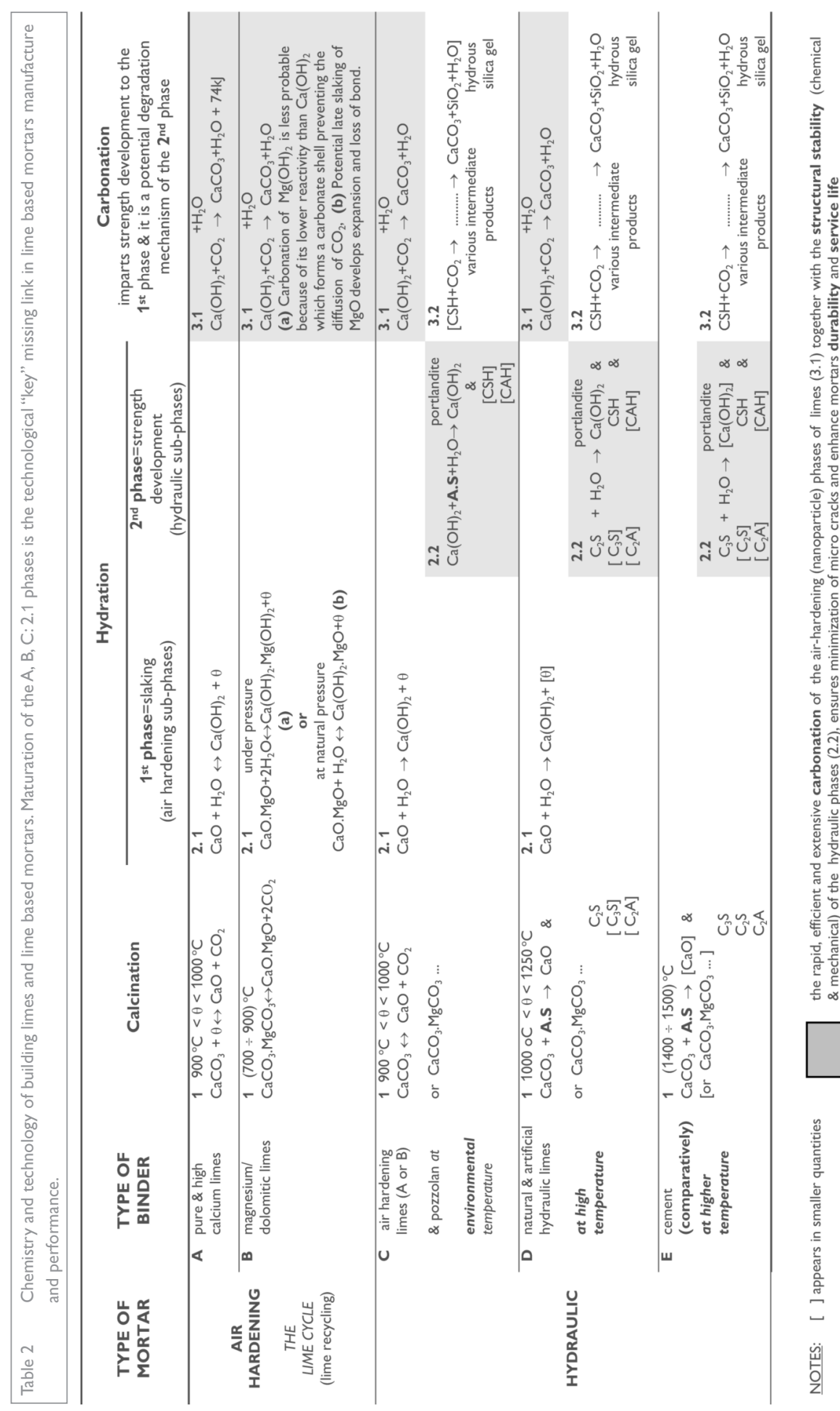

Conservar Património | Número_Issue 10 | 2009 
conservation practice the use of wet slaked lime putty is actually favoured only by skilled practitioners [50]. Instead, the use of dry hydrated limes is increasingly recommended [60], as they basically respond better to the conventional construction market demands $[48,61]$ i.e. they may be available in the market just after their production, have less mass volume, facilitate packaging, storage and transport, a range of mix proportions in mortars are easily prescribed, standardised and classified [47, 48], their economical viability shows potential, etc. Although it is known by experience that the conversion of dry slaked air-hardening limes into putties also improves their physical characteristics, little scientific information could be drawn from the literature about the differences between wet slaked lime putty and the putty made from dry hydrate [62, 63]; and no comparative evaluation could be found about their specific effect on mechanical characteristics of lime based mortars. Recent research has argued that putty deriving from a dry hydrate will never achieve the excellent qualities of wet slaked lime putty [64] reinforcing, thus, the empirical wisdom and technology. There is a marked indication that putty deriving from a dry hydrate originates an aggregation of particles oriented in a particular direction, while wet slaked lime putty favours random oriented particles producing, thus, better plasticity and workability [64].

As a conclusion, hydration chemistry describes both the slaking process of the air-hardening phases of limes and the main strength development mechanism of the hydraulic phases of limes. The use of wet slaked (hydrated) lime putty in conservation practice is recommended, as it possesses better rheological properties e.g. increased viscosity and yield stress in the fresh state [63] due to the plethora of colloidal (sub micrometer to nanometer) tabular-shaped $\mathrm{Ca}(\mathrm{OH})_{2}$ particles [56-59].

\section{Maturation: the "key" missing link}

It is apparent that the aging process of the wet slaked air-hardening lime putties provides a wide range of opportunities for the optimization of their physical characteristics. Hydraulic limes, on the contrary, cannot be improved by maturation, rendering the previous production processes more crucial for their quality.

The contradictory recommendations regarding the optimum period of aging - varying from 24 hours to decades $[15,16,34,49]$ - is somehow ascribed to an imprecise interpretation of the terms aging and maturing. Aging should relate to a broad technological term meaning the storage of wet slaked lime under excess water not necessarily connected to positive or negative effects on the lime's quality. The maturation mechanism comprises only the positive effects, corresponding thus to the aging period in which the quality of lime - e.g. in terms of the easily measured available lime $(K a)$, free water $\left(w_{F}\right)$ [46, 47, 61] and consistency - gradually improves. For this reason, the term matured lime putty is recommended for use in conservation literature and practice instead of the term aged lime putty.

It was reported that the ability of lime's upgrading appears to be limited (where a shelf-drying mechanism is the primary limiting factor) and may vary on a scale ranging from unacceptable through acceptable (CL70/CL80) to optimal (CL90) and vice versa $[52,65]$. The optimum maturation period for each case is technically predictable, though variable, and is clearly predisposed by the crucial technological factors applied in the previous production steps which, in turn, must be optimized according to the kind of limestone; the traditional mild processes finally being more suitable [52].

According to most up-to-date knowledge, the maturing process generates changes in the morphological and physical properties of lime and triggers better rheological properties - e.g. increased viscosity and yield stress in the fresh state [63] - identifying, thus, the first innovative nanotechnology widely used in human history [57]. In parallel, there is considerable development in the field of nanoparticle colloidal dispersions research; bearing in mind that particle size and nanoscale morphology can be manipulated to produce enhanced rheological properties, lime's maturation process becomes the 'key' missing link. It seems that the maturation process lasts as long as the stability (i.e. the balance of the repulsive and attractive forces) of lime's nanoparticle dispersion is assured. If the particles have little or no repulsive force then some instability mechanism will eventually take place e.g. flocculation, aggregation, etc.

The availability and the stability of the moisture (e.g. as optimal free water $w_{F}$ [47]) necessary for the dissolution of both carbon dioxide and calcium hydrate in water accelerate the carbonation and strength development rate. That, in turn, minimizes the crucial required time for a mortar to obtain its chemical and mechanical stability 
$[52,65]$. Hence, it would be intriguing to investigate if the traditional mild calcination and slaking procedures provide the only way to control the balance of the repulsive and attractive forces between the particles throughout decades and, consequently, if they are critical in optimizing the performance of a lime putty for as long as possible. Thus, contradiction about the optimum maturation period becomes understandable.

Concluding, the maturation of lime putty after wet slaking (Table 2, A, B, C: 2.1) ensured by the stability of lime's nanoparticle dispersion and the availability and the stability of an optimal amount of physically bound water [65] entail a surprisingly positive effect on the carbonation and strength development rate of the air-hardening lime mortars (and of the air-hardening parts of hydraulic mortars, as well) (Table 2, A, B, C: 3.1). Additionally, the expected range of improvement of the dry slaked air-hardening limes (Table 2, A, B, C: 2.1) from converting them in putties (and then by maturation) before use should be more investigated. It is implicit that any lime binder with hydraulic components (Table 2, D: 2.1) cannot be stored under excess water because of $\mathrm{CSH}$ formation and the consequent decrease in plasticity. Comparatively, in cement chemistry the term "maturation" expresses the decisive stage of the early strength development of cement mortars.

\section{Carbonation}

The early strength development of air-hardening limes is due to drying, while their actual consolidating properties are attributed to the reaction of carbonation. A labyrinth of controversies and debatable issues on the carbonation mechanism misleads conservation practice, especially given that the lime's affinity for carbon dioxide $\left(\mathrm{CO}_{2}\right)$ is, beside to its rheological properties, the basis for its historical use in construction [34]. The general exothermic reaction of Table 2, case A: 3.1 is, in fact, a multi-stage process in which several physicochemical parameters, involving solution phase reactions, affects the rate of the process; the sequence involves a $\mathrm{CO}_{2}$ diffusion progressing from the mortar surface to the core (drying), a dissolution of both $\mathrm{CO}_{2}$ and $\mathrm{Ca}(\mathrm{OH})_{2}$ on water (acting as a catalyst and being readily available as optimal $w_{F}$ ) followed by their reaction, finally resulting in the formation of calcium carbonate crystals $\mathrm{CaCO}_{3}$ (carbonation) and water, which tends to evaporate as the reaction is exothermic [57, 66-70]. In case B: 3.1, carbonation of $\mathrm{Mg}(\mathrm{OH})_{2}$ is not probable as it possesses lower reactivity than $\mathrm{Ca}(\mathrm{OH})_{2}$ (according to the Lyotropic series of chemical reactivity) and, thus, the shell of calcium carbonate crystals that is readily formed prevents the diffusion of $\mathrm{CO}_{2}$. Therefore, it is suggested that the reasons of the high mechanical strength of magnesium (dolomitic) mortars should be more investigated and documented microstructurally e.g. as owing to the grain morphology of the carbonate (pseudo-gel or dense/fine interconnected crystallites) [70]; and/or to 'the presence of foliated crystals rich in magnesium, probably hydromagnesite, which were located in porous and superficial areas' [71] developing an even more compact microstructure.

Conservation research has not been focussed on the rate and extent of carbonation of the air-hardening limes until the last decade. However, there was a consensus on the fact that the high surface/volume ratio of the minute plate like crystals of portlandite (formed either during slaking or at a greater extent during the maturation process) is responsible for the irreplaceable properties of lime such as plasticity, water retentiveness, high sand carrying capacity and high reactivity [ 34 , $56,65]$. Latest studies clearly document that matured lime putty grains had gradually undergone changes both in their crystal shape - from prisms to plate like - and in major crystal size reduction - from sub micrometer to nanometre - that greatly improve carbonation rate $[57,70,72]$. In the case of fresh putty mortars, carbonation follows a normal diffusion-limited continuous path succeeding from the mortar surface towards the core [66]. However, the carbonation of matured putty mortars differs considerably, following a quicker nonlinear reaction-diffusion process which results in periodic calcite precipitation organized as well-developed Liesegang patterns (concentric ellipsoids) [67-70, 73]. As expected, appropriate curing conditions such as water presence $(<80 \%)$, water vapour pressure, $\mathrm{pH}$, temperature, $\mathrm{CO}_{2}$ concentration or lime impurities also influence the carbonation mechanism [69].

As already mentioned, hydrated hydraulic limes consist of two parts - mainly $\mathrm{Ca}(\mathrm{OH})_{2}$ (air-hardening) and $\mathrm{CSH}$ (hydraulic) - which are both carbonated according to the reactions of Table 2, D:3.1 and 3.2 [54-56], finally 
generating $\mathrm{CaCO}_{3}$ crystals and poorly crystalline or amorphous hydrous silica gel $\left(\mathrm{SiO}_{2}+\mathrm{H}_{2} \mathrm{O}\right)$, through countless intermediate products. The partially carbonated portlandite $\mathrm{Ca}(\mathrm{OH})_{2}$ detected in ancient mortars is more likely originated by the soluble by-product of the hydration process (cases 2.2) [74]. The chemical and mechanical stability of the CSH formation seems to depend on its type (crystalline, semi-crystalline, amorphous) and on the environmental conditions that it is subjected to [12,74-75]. It is claimed that the stability of the CSH formation in a mortar greatly influences its strength and durability [53], as opposed to its carbonation. This is the reason why ancient mortars that have been subjected even to an aggressive environment are still in a very good state of conservation $[9,12,76]$.

In conclusion, carbonation is the predominant, though not unique, strength development mechanism of the air-hardening parts of limes. On the contrary, the carbonation of the hydraulic parts of limes (e.g. CSHs) should be considered as a potential mechanism of degradation (limited by CSH's stability).

\section{Conservation research and its efficiency on interventions}

After the '80s, an explosion of scientific research has been seen stimulating academic interest mainly in the characterisation and/or identification of historic mortars. Some fundamental material research studies exploit several advanced analytical techniques with the aim of enhancing our knowledge of the building limes' processes [39]; particularly, investigation is focussed on the mineralogical composition and the micro-morphological structure of the resulting hydraulic compounds of the reactions [39, 41], as demonstrated in Table 2 cases 2.2 and 3.3. Although the general reactions are the same, the determination of the chemical evolution of the resulting intermediate compounds, the rate of their strength development and, furthermore, the required period in order to obtain their chemical and mechanical stability, are difficult to define, especially on the mineral phases. Basic knowledge, which was developed by cement chemistry in relation to the study of the hydration products of portland cement (Table 2, case E), has already assisted the better understanding of the similar reactions occur- ring during the hydration process of natural and artificial hydraulic limes (case D) [54-55], since in all cases the hydraulic components are already formed during the burning process at high temperatures.

However, conservation research has faced great complications, regarding the study of the hydration products of the countless historic local lime-pozzolan mixtures (Table 2: case C) produced at natural environmental conditions, since the formation of the hydraulic compounds and the carbonation of the air-hardening parts occur simultaneously. It has been reported that 'physico-chemical adhesion and cohesion bonds developed at the matrix and at the binder/aggregate interface, respectively, become the key factor in interpreting the considerable durability that the historic mortars confer to the structures as bearing elements' [77]. In the latter case, the best documented reaction is that which occurs at the brick-lime interface, where 'on the lime side an enrichment by calcium silicates can be observed while on the brick side calcite deposition occurs' [41], obviously referring to the specific situation of (low fired) brick showing a pozzolanic reaction. At this point, the effect the (wet slaked) nanoparticle lime has on accelerating strength development rate and on enhancing structural stability must be pointed out, rendering maturation the 'key' missing link between the wisdom of empiricism technology and the conceit of modern chemistry.

The problem becomes much more complicated when bearing in mind that, after application and hardening, mortars will continuously interact with their environment producing transitional (new formation and/or alteration) compounds. All the potential combinations of causes, origins and degradation products in historic structures have been meticulously presented by Collepardi [78]. 'The presence of both lime inclusions and dissolution re-precipitation textures within a mortar present implications for any mortar analysis method which relates the quantity of calcium carbonate to the original binder content' [43]. Special thought must be given, thus, to the multi reported high binder/aggregate (B/A) ratio and the documentation of their interpretation. Apparently, it is often impossible to determine from what (historical) time the chemical compounds originate [44].

The more recently developed mortar characterisation and/or identification proposals - as a first step in the qualitative identification of the different components of 
the mortar - comprise optical microscopy for a first assessment of morphology and XRD techniques suitable to detect major crystalline phases [45, 79-80]. Several chemical and other analytical techniques are currently available for further qualitative and quantitative analyses like: a) scanning electron microscopy - energy dispersive X-ray spectrometry (SEM-EDX), b) microprobe spectrometry, c) thermal analysis for a quantitative determination of volatile phases and in particular differential scanning calorimetry (DSC) and/or differential thermal analysis (DTA) and/or thermogravimetric analysis (TGA) and d) Fourier transformed infrared spectroscopy (FT-IR) for the detection of minor or poorly crystalline phases or amorphous phases. The choice of the appropriate laboratory tests methodology and the interpretation of the results depend principally on the requested answers and on the proper sampling and field description, finally seeking out the optimal objectiveness of the whole process [81]. Acknowledging 'that the identification of the actual hydraulic components may not be necessary for either the characterisation of the mortar or the development of a successful formulation for its replacement' [41], the minimum number of key laboratory tests adequate to characterise a mortar, field observation and deep experience are equally required to enhance interventions' quality [82].

Hierarchically, the objective of the building heritage conservation field is the documentation of the different historical phases in a structure and that includes the assessment of the possible causes of degradation of old mortars, with the aim to support the designing of compatible repair mortars in terms of colour, texture, composition and physicochemical characteristics. Specific selection criteria according to each function of a mortar (structural, protective or decorative) may adjust priorities according to each unique case. Whereas some dichotomies related to binders have gradually found commonly accepted answers (e.g. cement vs. lime), some others still persist (e.g. dry hydrate vs. lime putty, strength vs. durability). It must be emphasised, though, that a number of criteria directly related to ancient and modern durability principles, such as the proper aggregates selection, their even gradation and the low water/binder (w/b) ratio (high w/b generally causes a decrease of the mortar quality with respect to mechanical and durability properties) are always valid.
However, recent research revealed that the higher water content of the air-hardening lime mortars increases porosity without necessarily resulting in strength reductions [52, 83]. Also, it was demonstrated that higher binder/aggregate $(B / A)$ content increases both total porosity and strength, though 'within a limit' [84]. Relevant research in lime pastes concluded that the high $w / b$ increases porosity by simply enlarging the distance between solid particles of calcite crystals with no effect to binder's pore surface [85]. Other studies documented that the degree of conversion of calcium hydroxide into carbonate is not the main factor controlling the strength of the binder [52], but also the morphology of the carbonate; well-developed crystalline structures and crystal habits of carbonate (favoured by $\mathrm{CO}_{2}$ gas pressure, exposure time and degree of compaction) give superior binder performances [86]. Since the binder matrix is the main factor of porosity in a lime mortar and the w/b ratio regulates porosity, strength development rate and ultimate strengths, more research is needed to investigate methodically the manufacture parameters focussing on lime binders' water retentiveness capability - which may control and optimize binders' strength and durability.

Today, the commonly accepted fundamental selection criteria for designing appropriate intervention mortars focus on: a) the hydraulicity of the binder, b) the (inert or active) aggregate nature (origin) and grading (sieving curve), c) the mixture proportions i.e. the binder/aggregate ratio $(B / A)$ and $d)$ the water/binder ratio $(w / b)$. At any case, the use of matured (nanoparticles wet slaked) lime putty is definitely positive.

In a masonry scale, it is well recognized that the correlation between the strength of masonry with lime mortar joints and the strength of the lime mortar itself is not linear; relatively weak lime mortar may produce high strength masonry [87]. In the particular case of masonry structures subjected to seismic loads, it is still suggested that 'the deformability characteristics of masonry at shear should be determined on the basis of experiments' [88].

Besides, grouting was verified as an efficient technique of enhancing the mechanical properties (compressive and shear) of typical historic vulnerable three-leaf stone masonry. Recent experimental investigations on alternative grouting mixtures (with better injectability and compatibility than pure cement grouts) have shown 
that samples with reduced cement content (ternary mixes) and hydraulic lime-based also upgrade the mechanical properties of masonry, even though the grouts' mechanical properties are lower [89]. It is believed that the contribution of the (nanoparticle wet slaked) lime putty in compatible injectable grouting should be more documented and pointed out.

Other structural studies concluded that the non-linear behaviour of masonry that allows the structure to absorb energy without affecting irreversibly its material properties' is due to the presence of stable CSH [12]. 'That CSH can be stable in geologic time is known, as it occurs naturally in a semi crystalline form (plombierite) or as tobermorite, gyrolite and xonotlite. The question whether or not man-made CSH in the form of concrete will be equally durable is more debatable, as the structure of $\mathrm{CSH}$ in normal concrete is amorphous, to some extent porous and laced with the soluble by-product of the hydration process, namely portlandite' [74] (Table 2). In historic mortars, the co-existence of crystalline and amorphous CSH has increasingly been reported, exhibiting higher crystallinity in lime-pozzolan mortars, where more free lime is available for reaction [90].

\section{Conclusions}

Concluding, the optimal structural behaviour of lime based mortars in historical masonries seems to rely on: a) the ability for rapid, efficient and extensive carbonation of the air-hardening phases of limes when matured (nanoparticle wet slaked) long-term stable lime putties are used, b) the chemical and mechanical stability of the strength components of the hydraulic phases of limes, originated from pozzolanic reactions (being higher in their more crystalline forms of historical lime-pozzolan mixtures than in their amorphous forms of modern cements), and c) the resulting excellent physicochemical adhesion and cohesion bonds at the matrix and at the binder/aggregate interface that ensures minimization of micro cracks and contributes to lime based mortars' durability and enhanced mechanical properties.

It is anticipated that the deep understanding of the favourable structural behaviour of traditional masonry construction with soft lime based mortars - compared to modern masonry with stiff and brittle mortars - in terms of tensile strength, fracture energy and ductility, will minimize intervention in monuments.

\section{References}

1 Von Landsberg, D., 'The history of lime production and use from early times to the industrial revolution', Zement-Kalk-Gips 6 (1992) 269-273 [in German], 8 199-203 [in English].

2 Malinowski, R.; Garfinkel, Y.; 'Prehistory of concrete', Concrete International (1991) 13(3) 62-68.

3 Stanley, C. C., Highlights in the History of Concrete, Cement and Concrete Association (1979) 43.

4 Davey, N., A History of Building Materials, Phoenix House, London (1961) 121-127.

5 Malinowski, R., 'Ancient mortars and concretes; durability aspects', in Mortars, Cements and Grouts used in the Conservation of Historic Buildings, Proceedings of the ICCROM Symposium, Rome, 3-6.11.1981, ICCROM, Rome (1982) 341-350.

6 Goria, C., 'Evoluzione storica dei leganti e dei conglomerati: dall' empirismo alla loro conoscenza razionale', in Cemento: Storia, Tecnologia, Applicazioni, Fratelli Fabbri Editori, Milan (1976) 45-80.

7 Malinowski, R., 'Concretes and mortars in ancient aqueducts', Concrete International 1 (1979) 66-76.

8 Efstathiadis, E., 'Greek concrete of three millenniums', Journal of Research Centre 17(1) (1978) [in Greek].

9 Papayianni, I., 'The longevity of old mortars', Applied Physics A: Material Science and Processing 83(4) (2006) 685-688.

10 Van Balen, K., 'Understanding the lime cycle and its influence on historical construction practice', in First International Congress on Construction History, Proceedings III, Madrid, 20th-24th January 2003 (2003) 2035-2039.

11 Tourptsoglou-Stefanidou, B., Byzantine Building Restrictions, Society of Macedonian Studies, Scientific Treatises, Law and Economic Series 6, Thessaloniki (1998) [in Greek].

12 Moropoulou, A.; Cakmak, A.S.; Biscontin, G.; Bakolas, A.; Zendri, E., 'Advanced Byzantine cement based composites resisting earthquake stresses: the crushed brick/lime mortars of Justinian's Hagia Sophia', Construction and Building Materials 16(8) (2002) 543-552.

13 Karaveziroglou, M.; Papayianni, J.; Penelis G., 'Mortars and grouts in restoration of Roman and Byzantine monuments', Compatible Materials for the Protection of European Cultural Heritage, the PACT Journal of the European Study Group on Physical, Chemical, Mathematical and Biological Techniques Applied to Archaeology, PACT 55, ed. G. Biscontin, A. Moropoulou, M. Erdik and J. Delgado Rodrigues, Technical Chamber of Greece, Athens (1998) 219-245.

14 Speweik, J. P., 'The history of masonry mortar in America 1720-1995', Lime News (Journal of the Building Limes Forum) 4(2) (1996) 5-19.

15 Vitruvius, M., The Ten Books on Architecture, translated by M. H. Morgan, Dover Publications, New York (1960), Book II, 35-64, BookVII, 195-220. 
16 Gaio Plinio Secondo, Naturalis Historia, G. Einaudi, Torino (1988), libro quinto, 709-711.

17 Palladio, A., The Four Books on Architecture, translated by R. Tavernor and R. Schofield, MIT Press, Cambridge (1997), Libri 4.

18 Alberti, L. B., Ten Books on Architecture, translated by J. Rykert, A. Tiranti, London (1955).

19 Higgins, B., Experiments and Observations, T. Cadell, London (1780) 35-38.

20 Smeaton, J., A Narrative of Building and a Description of the Construction of the Edystone Lighthouse with Stone, 2nd ed., G. Nicol, London (1793) Vicat, L. J., A Practical and Scientific Treatise on Calcareous Mortars and

21 Cements; Artificial and Natural, translated by Captain J. T. Smith, J.Weale, London (1837).

Burnell, G., Rudimentary Treatise on Limes, Cements, Mortars: Concretes,

22 Mastics, Plastering etc., 14th ed., Crosby Lockwood and Son, London (1892).

Dibdin, W. J., Tests of Limes and Sands. Report to the Royal Institute of

23 British Architects (1911).

Leduc, E. ; Chenu, G., Chaux, Ciments et Plâtres, Paris (1912).

24 Eckels, E. C., Cements, Lime and Plasters, John Wiley, New York (1922).

25 Knibbs, N.V. S., Lime and Magnesia, Ernest Benn, London (1924).

26 Hasak, M.; 'Mörteltechnik-Einiges über den Loriotschen Mörtel und

27 über den mittelalterlichen Mörtel', Tonindustrie-Zeitung 49(77) (1925) 1080-1081.

Anstett, F., Essai et Analyse des Matériaux de Construction et de Travaux

28 Publics, Paris (1927).

Cower, A. D., 'Lime and lime mortars', in Building Research Special

29 Report 9, HMSO (1927) 74-76.

Kuhl, H., Zement 18, 833 (1929).

30 Grun, R., 'Zusammensetzung und Beständigkeit von 1850 Jahre

31 altem Beton', Angewandte Chemie 7 (1935) 124-127.

Knight, B., Builders' Materials, Edward Arnold \& Co., London (1939).

32 Mitchell, G., Mitchell's Building Construction - Elementary Course, B. T.

33 Batsford Ltd, London (1943), reprinted in Lime News Journal of the Building Limes Forum) 3(1) (1994) 63.

Boynton, R. S., The Chemistry and Technology of Lime and Limestone,

34 2nd ed., J.Wiley \& Sons, New York (1980).

Phillips, M.W., 'Conference Summary', APT Bulletin 6(1) (1974) 9-39.

35 Alessandrini, G., 'L' Intonaco: Storia, Cultura e Technologia', in Atti del

36 convegno di Studi, Bressanone 24-27 Giugno 1985, Libreria Progetto Editore, Padova (1985) 9-39.

Torraca, G., 'Lime technology in architectural conservation', Lime

37 News (Journal of the Building Limes Forum) 4(1) (1995) 34-41.

Mortars, Cements and Grouts used in the Conservation of Historic

38 Buildings. Symposium, Rome, 3-6 November 1981, ICCROM, Rome (1982).

Elsen, J., 'Microscopy of historic mortars - a review', Cement and

39 Concrete Research 36 (2006) 1416-1424.

40 Stewart, J.; Moore, J., 'Chemical techniques of historic mortar analysis', APT Bulletin 14(1) (1982) 11-16.
41 Charola, A. E.; Henriques, F., 'Hydraulicity in lime mortars revisited', RILEM TC-167COM International Workshop on Historic Mortars: Characteristics and Tests, University of Paisley, Scotland (1999).

42 Lindqvist, J. E.; Nijland, T.; Von Konow, T.; Wester, Plesser T.; Nyman, P.; Larbi, J.; Van Hees, R., 'Analysis of mortars with additives', http://www.nordicinnovation.net/nordtestfiler/rep594.pdf (accessed 2 February 2010).

43 Leslie, A. B.; Hughes, J. J., 'Binder microstructure in lime mortars: implications for the interpretation of analysis results', Quarterly Journal of Engineering Geology \& Hydrogeology 35(3) (2002) 257-263.

44 Callebaut, K., 'State of the art of research/diagnostics of historical building materials in Belgium', http://www.arcchip.cz/w09/w09_callebaut.pdf (accessed 2 November 2005).

45 RILEM TC 167-COM, 'Characterisation of Old Mortars with Respect to their Repair', Final Report rep028, ed. C. Groot, G. Ashall and J. Hughes (2004).

46 Zacharopoulou G., 'The Renascence of Lime Based Mortar Technology. An appraisal of a bibliographic study', Compatible Materials for the Protection of European Cultural Heritage, the PACT Journal of the European Study Group on Physical, Chemical, Mathematical and Biological Techniques Applied to Archaeology, PACT 55, ed. G. Biscontin, A. Moropoulou, M. Erdik and J. Delgado Rodrigues, Technical Chamber of Greece, Athens (1998) 89-114.

47 EN 459, Building Lime-Part 1: Definitions, Specifications and Conformity Criteria 459.02: Building Lime-Part 2: Test Methods, 459.03: Building Lime-Part 3: Conformity Evaluation, CEN (2000) (revision towards approval by CEN in 2010).

48 EN 998, Specification for Mortar for Masonry-Part 1: Rendering/Plastering, Specification for Mortar for Masonry-Part 2: Masonry Mortar, CEN (2000).

49 Wingate, M., Small-Scale Lime-Burning. A Practical Introduction, Intermediate Technology Publications, London (1985).

50 Holmes, S.; Wingate, M., Building with Lime. A Practical Introduction, Intermediate Technology Publications, London (1997).

51 Moropoulou,A.; Bakolas, A.; Aggelakopoulou, E., 'The effects of limestone characteristics and calcination temperature to the reactivity of the quicklime', Cement and Concrete Research 31 (2001) 633-639.

52 Zacharopoulou, G., 'Building Lime of High Reactivity Suitable for the Conservation of Monuments and Historical Buildings', PhD thesis, Aristotle University of Thessaloniki, Greece (2004), 408 pp. [in Greek], available online by the National Documentation Centre (NDC) - Hellenic PhD Dissertations Thesis, http://thesis.ekt.gr/14566.

53 Brown, P.W.; Clifton, J. R., 'Mechanisms of deterioration in cementbased materials and lime mortar', Durability of Building Materials 15(5) (1988) 409-420.

54 Czernin,W., Cement Chemistry and Physics for Civil Engineers, 2nd ed., Georg Godwin, London (1980).

55 Lea, F. M., The Chemistry of Cement and Concrete, 3rd ed., Arnold Ltd, London (1988) 415-453. 
56 Torraca, G., Porous Building Materials - Materials Science for Architectural Conservation, 3rd ed., ICCROM, Rome (1988).

57 Elert, K.; Rodriguez-Navarro, C.; Pardo, E.S.; Hansen, E.; Cazalla, O., 'Lime mortars for the conservation of historic buildings', Studies in Conservation 47 (2002) 62-75.

58 Wisser, S.; Kraus, K.; Knöfel, D., 'Composition and properties of historical lime mortars', in Vlth International Congress on Deterioration and Conservation of Stone, Torun', 12-14 September 1988, ed. by J.Ciabach, Nicolas Copernicus University Press Dept., Torun (1988) 484-491.

59 Knöfel, D.,'Old and new mortars. Material analyses and recommendations concerning historical masonry', in Conservation of Historic Brick Structures, Proceedings of the 3rd Expert Meeting, NATO-CCMS Pilot Study Hamburg, 2-4 November 1989, Umweltbundesamt, Berlin (1990) 64-86.

60 Callebaut, K.;Van Balen, K.,'Dry-slaked lime: an alternative binder for restoration mortars', in 1st International Workshop on Urban Heritage and Building Maintenance VII 'Maintenance and strengthening of materials and structures: Plaster', Zurich (2000) 65-72.

61 Zacharopoulou, G., 'Lime outdoors, lime indoors: the virtue of water retentiveness', EUROCARE Newsletter 4 (2005) 8.

62 Faria, P.; Henriques, F.; Rato, V., 'Comparative evaluation of lime mortars for architectural conservation', Journal of Cultural Heritage 9 (2008) 338-346.

63 Atzeni, C.; Farci, A.; Floris, D.; Meloni, P., ‘Effect of aging on rheological properties of lime putty', Journal of American Ceramic Society 87(9) (2004) 1764-1766.

64 Rodriguez-Navarro, C.; Ruiz-Agudo, E.; Ortega-Huertas, M.; Hansen, E., 'Nanostructure and irreversible colloidal behaviour of $\mathrm{Ca}(\mathrm{OH})_{2}$ : Implications in cultural heritage conservation,' Langmuir 21 (2005) 10948-10957.

65 Zacharopoulou, G., 'Greek air-hardening building lime putties', Lime News (Journal of the Building Limes Forum) 13 (2006) 88-93.

66 Van Balen, K., 'The Influence of Carbonation of Lime Mortars on the Properties of Historic Masonry Structures', PhD thesis, University of Louvain, Belgium (1991) [in Dutch].

67 Cazalla, O.; Rodriguez-Navarro, C.; Sebastian, E.; Cultrone, G., 'Aging of lime putty: Effects on traditional lime mortar carbonation', Journal of the American Ceramic Society 83(5) (2000) 1070-1076.

68 Radonjic, M.; Hallam, K. R.; Allen, G. C.; Hayward, R. J., 'The mechanism of carbonation in lime-based materials', Lime News (Journal of the Building Limes Forum) 8 (2001) 50-64.

69 Hansen, E.; Van Balen, K.; Rodriguez-Navarro, C., 'Variations in lime mortar properties resulting from the use of freshly slaked quicklime, aged slaked lime, and commercial dry hydrated lime', http://www.lime.org/ BLG (accessed 2 March 2005).

70 Beruto, D. T.; Barberis, F.; Botter, R., 'Calcium carbonate binding mechanisms in the setting of calcium and calcium-magnesium puttylimes', Journal of Cultural Heritage 6 (2005) 253-260.

71 Adriano, P.; Silva, A. S.; Veiga, R.; Mirão, J.; Candeias, A. E., 'Microscopic characterisation of old mortars from the Santa Maria church in Évora', in 11th Euroseminar on Microscopy Applied to Building Materials, 5-9 June 2007, Porto, Portugal, http://cathedral.Inec.pt/publicacoes/c9.pdf (accessed 23 January 2010).

72 Lawrence, R. M. H., 'A critical review of techniques used to assessment of carbonation in lime mortars', in International Building Lime Symposium 2005, Orlando, Florida, March 9 -11, 2005, http://www.nationallime.org//BLS05Papers/Lawrence.pdf (accessed 2 February 2010).

73 Rodriguez-Navarro, C.; Cazalla, O.; Elert, K., Sebastian, E., 'Liesegang pattern development in carbonating traditional lime mortars', The Royal Society Proceedings Series A 458(2025) (2002) 2261-2273.

74 Pettifer, K., 'A Petrographic Investigation of Ancient Mortars', personal discussion at BRE on March 1993 on his Special Report 44/86, ed. BRE, Garston, Watford (1986).

75 Rayment, D. L.; Pettifer, K., 'Examination of durable mortar from Hadrian's Wall', Materials Science and Technology 3 (1987) 997-1004.

76 Jordan, J.W.; Brookes, C. L., 'The Conservation and Strengthening of Masonry Structures', http://www.gifford.uk.com/publications/7AMC-Newcastle-2004.pdf_(accessed 2 March 2005).

77 Moropoulou, A.; Bakolas, A.; Bisbikou, K., 'Physico-chemical adhesion and adhesion bonds in joint mortars imparting durability to the historic structures', Construction and Building Materials 14(1) (2000) 35-46.

78 Collepardi, M.,'Degradation and restoration of masonry walls of historical buildings', Materials and Structures 23 (1990), 81-102.

79 Bartos, P.; Groot, C.; Hughes, J. (ed.), Historic Mortars: Characteristics and Tests, University of Paisley, Scotland (2000).

80 Charola, A. E.; Henriques, F., 'Lime mortars: some consideration on testing standardization', in Use of and need for preservation standards in architectural conservation, ASTM STP 1355, R.C. McClug, American Society of Testing Materials, http://www.dec.fct.unl.pt/seccoes/smtc/pub16.pdf (accessed 31 January 2007).

81 RILEMTC 203-RHM, Repair mortars for historic masonry. Testing of hardened mortars, a process of questioning and interpreting', Materials and Structures, 42(7) (2009) 853-865.

82 Teutonico, J. M.; Fiddler, J., 'Time for change:An overview of building-materials research for conservation of historic structures', APT Bulletin, 29(3-4) (1998) 45-49.

83 Lawrence, R. M. H.;Walker, P., 'The impact of the water/lime ratio on the structural characteristics of air lime mortars', in Structural Analysis of Historic Construction:Preserving Safety and Significance. Proceedings of the VI International Conference on Structural Analysis of Historic Construction, SAHC08, 2-4 July 2008, Bath, ed. D. F. D' Ayala and E. Fodde, Taylor \& Francis Group, London (2008) 885-889.

84 Lanas, J.;Alvarez-Galindo, J., 'Masonry repair lime-based mortars: factors affecting the mechanical behaviour', Cement and Concrete Research 33(11) (2003) 1867-1876.

85 Arandigoyen, M.; Bernal, J. L. Pérez; López, M. A. Bello; Alvarez, J. I., 'Lime-pastes with different kneading water: Pore structure and capillary porosity', Applied Surface Science 252(5) (2005) 1449-1459. 
86 Silva, P.; Bucea, L.; Moorehead, D. R.; Sirivivatnanon, V., 'Carbonate binders: Reaction kinetics, strength and microstructure', Cement \& Concrete Composites 28 (2006) 613-620.

87 Karaveziroglou, M.; Papayianni, J., 'Compressive Strength of Masonry with Thick Mortar Joints', in RILEM Congress on the Conservation of Stone and other Materials, 29th of June 1993, Paris (1993) 1-8.

88 Tomaževič, M., 'Shear resistance of masonry walls and Eurocode 6: shear versus tensile strength of masonry', Materials and Structures 42 (7) (2009) 889-907.

89 Vintzileou, E.; Miltiadou-Fezans,A.,'Mechanical properties of three-leaf stone masonry grouted with ternary or hydraulic lime-based grouts', Engineering Structures 30 (2008) 2265-2276.

90 Pavía, S., 'A petrographic study of mortar hydraulicity', in HMC08, Historical Mortars Conference: Characterization, Diagnosis, Conservation, Repair and Compatibility, Lisbon, 24-26 September 2008, Laboratório Nacional de Engenharia Civil, Lisbon (2008). 